\title{
Novel $\mathrm{Pd}$ promoted $\mathrm{Ag} / \mathrm{Al}_{2} \mathrm{O}_{3}$ catalyst for the selective reduction of $\mathrm{NO}_{x}$
}

\author{
Hong $\mathrm{He}^{*}$, Jin Wang, Qingcai Feng, Yunbo Yu, Kiyohide Yoshida \\ Research Center for Eco-Environmental Sciences, Chinese Academy of Sciences, Beijing 100085, China
}

Received 4 April 2003; received in revised form 28 May 2003; accepted 28 May 2003

\begin{abstract}
A novel palladium promoted $\mathrm{Ag} / \mathrm{Al}_{2} \mathrm{O}_{3}$ catalyst (denoted $\mathrm{Ag}-\mathrm{Pd} / \mathrm{Al}_{2} \mathrm{O}_{3}$ ) has been developed for the selective catalytic reduction of $\mathrm{NO}$ by $\mathrm{C}_{3} \mathrm{H}_{6}$. The $\mathrm{Ag}-\mathrm{Pd} / \mathrm{Al}_{2} \mathrm{O}_{3}$ shows a higher $\mathrm{NO}_{x}$ conversion than $\mathrm{Ag} / \mathrm{Al}_{2} \mathrm{O}_{3}$, especially at the temperatures ranging from 300 to $450{ }^{\circ} \mathrm{C}$. The addition of a small amount of $\mathrm{Pd}(0.01 \mathrm{wt} . \%)$ to $\mathrm{Ag} / \mathrm{Al}_{2} \mathrm{O}_{3}$ is considered to be favorable for the partial oxidation of $\mathrm{C}_{3} \mathrm{H}_{6}$. In situ diffuse reflectance infrared Fourier transform spectroscopy (DRIFTS) suggest that the presence of $\mathrm{Pd}$ catalyzes the formation of enolic species which is converted from $\mathrm{C}_{3} \mathrm{H}_{6}$. The enolic species is very active towards $\mathrm{NO}_{2}$ and $\mathrm{NO}_{3}{ }^{-}$, resulting in the formation of $-\mathrm{NCO}$ species which is the key reaction intermediate in the selective catalytic reduction of NO.
\end{abstract}

(C) 2003 Elsevier B.V. All rights reserved.

Keywords: Ag-Pd/ $/ \mathrm{Al}_{2} \mathrm{O}_{3}$; Selective catalytic reduction of $\mathrm{NO}_{x}$; Enolic species; In situ DRIFTS; Catalytic reaction mechanism

\section{Introduction}

Since Iwamoto and co-workers [1,2] and Held et al. [3] first reported that Cu-ZSM-5 is an effective catalyst for the selective catalytic reduction (SCR) of NO by hydrocarbons in the presence of excess oxygen, the SCR of $\mathrm{NO}_{x}$ has received much attention as a kind of potential technology for cleaning $\mathrm{NO}_{x}$ in various oxygen-rich exhausts of diesel engine, lean burn gasoline engine and gas engine. In the recent studies [4-12], alumina-supported silver catalysts (denoted $\mathrm{Ag} / \mathrm{Al}_{2} \mathrm{O}_{3}$ ), which are relatively durable and inexpensive, are considered to be a candidate for practical use. However, the $\mathrm{NO}_{x}$ conversion over $\mathrm{Ag} / \mathrm{Al}_{2} \mathrm{O}_{3}$ is quite low at low temperature range of $300-400^{\circ} \mathrm{C}$, which is a major disadvantage. On

\footnotetext{
* Corresponding author. Tel.: +86-10-62849123; fax: +86-10-62923563.

E-mail address: honghe@mail.rcees.ac.cn (H. He).
}

the other hand, catalysts based on platinum-group metals, such as well-known three-way catalysts, can eliminate $\mathrm{NO}_{x}, \mathrm{CO}$ and unburned hydrocarbons all together in an exhaust of gasoline engines which operate close to stoichiometric condition. Unfortunately, those catalysts are almost all ineffective for the selective reduction of $\mathrm{NO}_{x}$ in the presence of excess oxygen when the temperature is over $400{ }^{\circ} \mathrm{C}$ $[13,14]$.

We first reported on 69th Annual Meeting of JCS [15] that the selective reduction of $\mathrm{NO}$ with $\mathrm{C}_{3} \mathrm{H}_{6}$ over $\mathrm{Ag} / \mathrm{Al}_{2} \mathrm{O}_{3}$ catalyst was effectively enhanced by co-impregnating a small amount of $\mathrm{Pd}$, and the negative additive effect of $\mathrm{Pt}$ and $\mathrm{Au}$. The additive effect of $\mathrm{Pd}$ on $\mathrm{Ag} /$ mordenite was also reported by Masuda et al. [16] using $\left(\mathrm{CH}_{3}\right)_{2} \mathrm{O}$ as a reductant although the durability of $\mathrm{Ag} / \mathrm{Pd} /$ mordenite was decreased in the presence of water vapor. Seker et al. [17] showed the negative effect of $\mathrm{Au}$ on $\mathrm{Ag} / \mathrm{Al}_{2} \mathrm{O}_{3}$ for the $\mathrm{NO}_{x}$ reduction with $\mathrm{C}_{3} \mathrm{H}_{6}$. However, the mechanism of additive 
effect of platinum-group metals on Ag based catalysts is still unclear.

In this study, we prepared and investigated a novel Ag-Pd/ $/ \mathrm{Al}_{2} \mathrm{O}_{3}$ for the SCR of NO by $\mathrm{C}_{3} \mathrm{H}_{6}$. We have made in situ diffuse reflectance infrared Fourier transform spectroscopy (DRIFTS) observation of surface species formed on $\mathrm{Ag}-\mathrm{Pd} / \mathrm{Al}_{2} \mathrm{O}_{3}$ and $\mathrm{Ag} / \mathrm{Al}_{2} \mathrm{O}_{3}$ to investigate the mechanism of $\mathrm{Pd}$ additive effect during the SCR of NO.

\section{Experimental}

\subsection{Catalyst preparation}

The $\mathrm{Ag} / \mathrm{Al}_{2} \mathrm{O}_{3}$ (Ag metal loading: 5 wt.\%) and $\mathrm{Pd}-\mathrm{Ag} / \mathrm{Al}_{2} \mathrm{O}_{3}$ catalysts were prepared by an impregnation method. The $\gamma-\mathrm{Al}_{2} \mathrm{O}_{3}$ powder $\left(200 \mathrm{~m}^{2} \mathrm{~g}^{-1}\right)$ was dissolved in an appropriate amount of silver nitrate or silver nitrate and palladium nitrate mixed in aqueous solution. This was followed by evaporation to dryness in a rotary evaporator at $60^{\circ} \mathrm{C}$ under reduced pressure. The resulting paste was dried at $120^{\circ} \mathrm{C}$ overnight, and then calcined in air at $600{ }^{\circ} \mathrm{C}$ for $3 \mathrm{~h}$. Before catalytic test, the catalysts were sieved into 20-40 meshes.

\subsection{Catalytic tests}

The catalytic test was measured with a fixed-bed quartz flow reactor $(10 \mathrm{~mm}$ i.d.) by passing a mixture of $800 \mathrm{ppm} \mathrm{NO}, 1714 \mathrm{ppm} \mathrm{C}_{3} \mathrm{H}_{6}$, and $10 \mathrm{vol} . \%$ $\mathrm{O}_{2}$ in high pure $\mathrm{N}_{2}$ at a rate of $4000 \mathrm{~cm}^{3} \mathrm{~min}^{-1}$ over $1.2 \mathrm{~g}$ catalyst $\left(W / F=0.018 \mathrm{~g} \mathrm{~s} \mathrm{~cm}^{-3}\right.$, GHSV $\left.=\sim 50,000 \mathrm{~h}^{-1}\right) . \mathrm{H}_{2} \mathrm{O}$ vapor $(10$ vol. $\%$ ) was supplied with a syringe pump and vaporized by a coiled heater set at inlet of the reactor. Water was removed from the reactor effluent gas by passing a condenser instrument before reaching on line analyzers. After reaching steady state, the effluent gas was analyzed by AVL Di Gas, 4000 light for $\mathrm{HC}$ conversion analyses and a chemiluminescence $\mathrm{NO} / \mathrm{NO}_{2} / \mathrm{NO}_{x}$ analyzer $(42 \mathrm{C}-\mathrm{HL}$, Thermo Environmental) for $\mathrm{NO}_{x}$ conversion analyses.

\subsection{In situ diffuse reflectance infrared Fourier transform spectroscopy procedure}

In situ DRIFTS spectra were recorded in a NEXUS 670-FTIR equipped with a smart collector and a
MCT/A detector cooled by liquid $\mathrm{N}_{2}$. The sample for studies (ca. $30 \mathrm{mg}$ ) was finely ground and placed in a ceramic crucible. Prior to each experiment, the catalyst was firstly heated in the flow of $10 \mathrm{vol} . \% \mathrm{O}_{2}+\mathrm{N}_{2}$ for $60 \mathrm{~min}$ at 300 and $600^{\circ} \mathrm{C}$, respectively, then cooled to $400{ }^{\circ} \mathrm{C}$ and exposed to $10 \mathrm{vol} . \% \mathrm{O}_{2}+\mathrm{N}_{2}$ for $30 \mathrm{~min}$, and a spectrum of the catalyst in the flow of $\mathrm{N}_{2}+\mathrm{O}_{2}$ served as the background was recorded. All spectra were measured under real reaction conditions with a resolution of $4 \mathrm{~cm}^{-1}$ and accumulation of 100 scans.

\section{Results and discussion}

\subsection{Activity measurements}

Fig. 1(a) shows the $\mathrm{NO}_{x}$ reduction activity of $\mathrm{Ag} / \mathrm{Al}_{2} \mathrm{O}_{3}$ and $\mathrm{Ag}-\mathrm{Pd} / \mathrm{Al}_{2} \mathrm{O}_{3}$ catalysts, respectively, at various temperatures. Both $\mathrm{NO}_{x}$ conversions increased with the increase of reaction temperature and reached a maximum at $437^{\circ} \mathrm{C}$ for $\mathrm{Ag}-\mathrm{Pd} / \mathrm{Al}_{2} \mathrm{O}_{3}$ and at $470{ }^{\circ} \mathrm{C}$ for $\mathrm{Ag} / \mathrm{Al}_{2} \mathrm{O}_{3}$, then decreased with the further increase of reaction temperature. The highest rate of $\mathrm{NO}_{x}$ conversion was $82 \%$ over $\mathrm{Pd}-\mathrm{Ag} / \mathrm{Al}_{2} \mathrm{O}_{3}$, higher than that of $73 \%$ over $\mathrm{Ag} / \mathrm{Al}_{2} \mathrm{O}_{3}$. Obviously, a trace amount of $\mathrm{Pd}$ added into $\mathrm{Ag} / \mathrm{Al}_{2} \mathrm{O}_{3}$ could enhance the $\mathrm{NO}_{x}$ conversion in the presence of excess oxygen and water vapor. This metal additive effect is considered to be favorable for activating reductant molecule; for example, scission of a $\mathrm{C}-\mathrm{C}$ bond and partial oxidation.

Fig. 1(b) shows the conversions of propene into $\mathrm{CO}_{x}$ over $\mathrm{Pd}-\mathrm{Ag} / \mathrm{Al}_{2} \mathrm{O}_{3}$ and $\mathrm{Ag} / \mathrm{Al}_{2} \mathrm{O}_{3}$. Similar to the $\mathrm{NO}_{x}$ conversion, the curve of $\mathrm{C}_{3} \mathrm{H}_{6}$ conversion for $\mathrm{Ag} / \mathrm{Al}_{2} \mathrm{O}_{3}$ was shifted to lower temperature by Pd addition. This result suggests that $\mathrm{Ag}-\mathrm{Pd} / \mathrm{Al}_{2} \mathrm{O}_{3}$ can activate $\mathrm{C}_{3} \mathrm{H}_{6}$ to react with $\mathrm{NO}+\mathrm{O}_{2}$.

\subsection{In situ steady-state DRIFTS of the $N O_{x}$ reduction over $\mathrm{Ag}-\mathrm{Pd} / \mathrm{Al}_{2} \mathrm{O}_{3}$ and $\mathrm{Ag} / \mathrm{Al}_{2} \mathrm{O}_{3}$}

For directly investigating the effect of Pd addition under real catalytic reaction conditions, we carried out experiments using in situ DRIFTS. Conditions for in situ DRIFTS are the same as those in Fig. 1, namely, 800 ppm NO +10 vol. $\% \mathrm{O}_{2}+1714$ ppm $\mathrm{C}_{3} \mathrm{H}_{6}$. All in situ DRIFTS spectra shown in Fig. 2 are recorded in the steady state at various temperatures of 200 , 

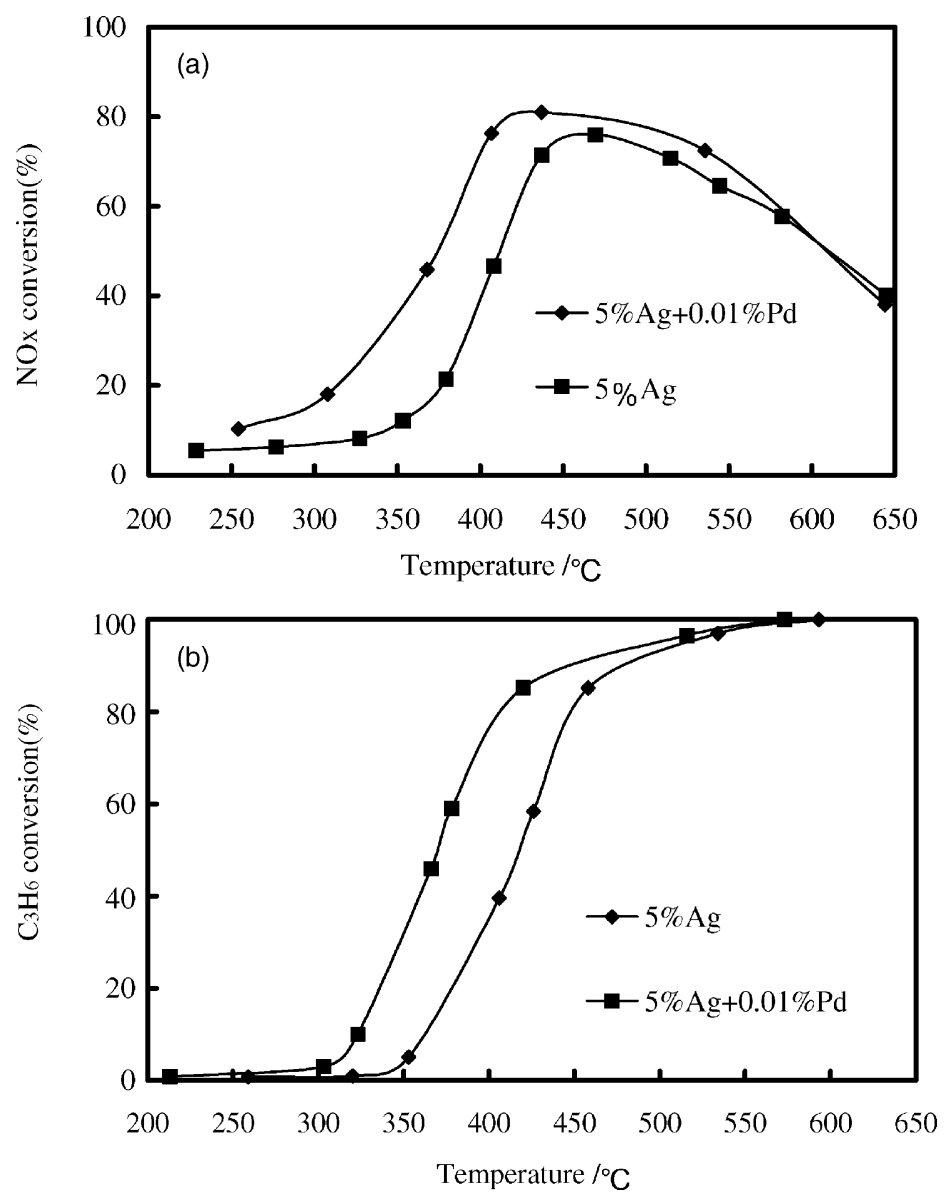

Fig. 1. (a) The catalytic activity for $\mathrm{NO}_{x}$ reduction by $\mathrm{C}_{3} \mathrm{H}_{6}$ over $\mathrm{Ag} / \mathrm{Al}_{2} \mathrm{O}_{3}$ and $\mathrm{Ag}-\mathrm{Pd} / \mathrm{Al}_{2} \mathrm{O}_{3}$ catalyst, respectively, at various temperatures in the presence of water vapor. Reaction conditions: $800 \mathrm{ppm} \mathrm{NO}, 1714 \mathrm{ppm} \mathrm{C}_{3} \mathrm{H}_{6}, 10$ vol. $\% \mathrm{O}_{2}, 10$ vol. $\%$ water vapor, $W / F=0.018 \mathrm{~g} \mathrm{~s}^{-3}$, GHSV $=\sim 50,000 \mathrm{~h}^{-1}, \mathrm{~N}_{2}$ balance, total flow rate $=4000 \mathrm{ml} / \mathrm{min}$. (b) Conversions of propene into $\mathrm{CO}_{x}$ over $\mathrm{Ag}-\mathrm{Pd} / \mathrm{Al}_{2} \mathrm{O}_{3}$ and $\mathrm{Ag} / \mathrm{Al}_{2} \mathrm{O}_{3}$, respectively, at various temperatures in the presence of water vapor. Reaction conditions: the same as in (a).

250, 300, 350, 400 and $450^{\circ} \mathrm{C}$. After an exposure of the catalyst to $\mathrm{NO}+\mathrm{C}_{3} \mathrm{H}_{6}+\mathrm{O}_{2}$ mixture gas for $60 \mathrm{~min}$ at $200^{\circ} \mathrm{C}$, as shown in Fig. 2, many IR peaks appeared in the region between 1700 and $1300 \mathrm{~cm}^{-1}$. According to the previous literatures $[12,18,19]$, the strong bands at 1651,1591 , and $1392 \mathrm{~cm}^{-1}$ were attributed to $v(-\mathrm{ONO}), v\left(-\mathrm{NO}_{2}\right)$ and $\delta\left(-\mathrm{CH}_{3}\right)$, respectively, which suggested that the organic compounds $\mathrm{C}_{x} \mathrm{H}_{y} \mathrm{NO}_{z}\left(\mathrm{R}-\mathrm{ONO}\right.$ and $\left.\mathrm{R}-\mathrm{NO}_{2}\right)$ were largely formed on the catalyst surface at $200{ }^{\circ} \mathrm{C}$. The peaks at 1300 and $1580 \mathrm{~cm}^{-1}$ were assigned to the bidentate nitrates and monodentate nitrates, respectively $[7,12,20]$. The peaks at 1562 and $1454 \mathrm{~cm}^{-1}$ are assigned to $\nu_{\mathrm{as}}(\mathrm{COO})$ and $\nu_{\mathrm{s}}(\mathrm{COO})$ of the adsorbed acetate [20-23]. When we increased the reaction temperature, as shown in Fig. 2, the strong band at $1651 \mathrm{~cm}^{-1}$ disappeared gradually, while the weak band at $2239 \mathrm{~cm}^{-1}$ can still be observed. This feature has been observed in our previous works [11,12] and assigned to isocyanate $(-\mathrm{NCO})$ species, which is a key intermediate species, reported by many researchers [7-9,14].

Fig. 3 shows the IR spectra of $\mathrm{Ag}-\mathrm{Pd} / \mathrm{Al}_{2} \mathrm{O}_{3}$ catalyst in the flow of $\mathrm{NO}+\mathrm{C}_{3} \mathrm{H}_{6}+\mathrm{O}_{2}$ in the steady state at various temperatures. Based on the comparison between Figs. 2 and 3, the bands at 1300, 1580, 1572, 1460 (1460-1475), 1597 and $1394 \mathrm{~cm}^{-1}$ are similarly assigned to bands of adsorbed nitrates, acetate and 


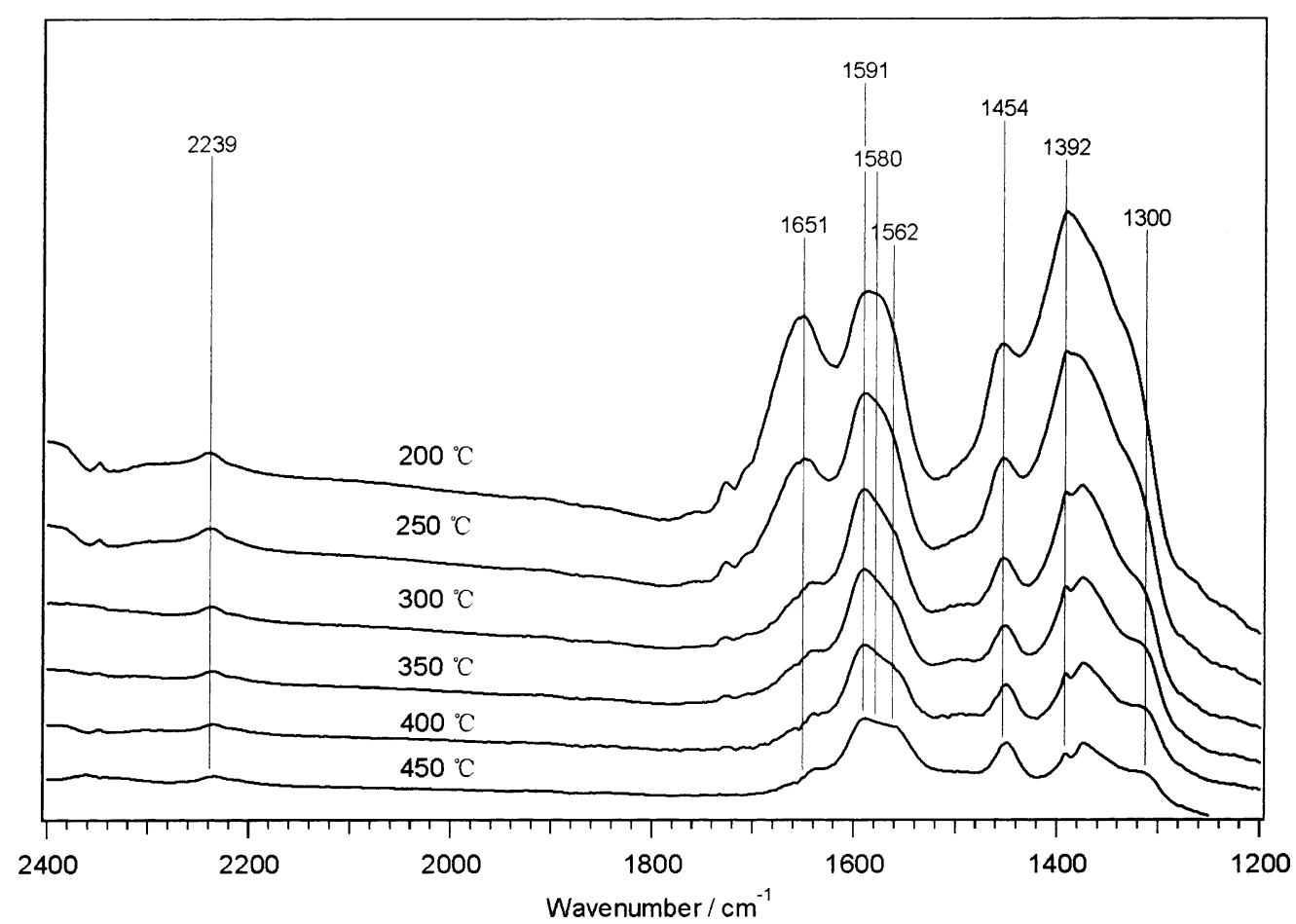

Fig. 2. In situ DRIFTS spectra of $\mathrm{Ag} / \mathrm{Al}_{2} \mathrm{O}_{3}$ in a steady state at various temperatures in a flow of $\mathrm{C}_{3} \mathrm{H}_{6}+\mathrm{O}_{2}+\mathrm{NO}$. Feed: the same as in Fig. 1.

$\mathrm{R}-\mathrm{NO}_{2}$ species. The principle difference between Figs. 2 and 3 is the new peak on $\mathrm{Ag}-\mathrm{Pd} / \mathrm{Al}_{2} \mathrm{O}_{3}$ catalyst at $1637 \mathrm{~cm}^{-1}$, along with the missing peak at $1651 \mathrm{~cm}^{-1}$ which has been assigned to the band of $\mathrm{R}-\mathrm{ONO}$ in Fig. 2. Another new band at $2158 \mathrm{~cm}^{-1}$ can be assigned to $-\mathrm{CN}$ surface species $[12,24]$. Similar peak at $1630 \mathrm{~cm}^{-1}$ was also observed on $\mathrm{Ag} / \mathrm{Al}_{2} \mathrm{O}_{3}$ in the flow of $n$-hexane $+\mathrm{NO}+\mathrm{O}_{2}$ and assigned to carbonate species [20]. Turek et al. [25] reported that when $\mathrm{CO}_{2}$ chemisorbed on the surface of $\gamma-\mathrm{Al}_{2} \mathrm{O}_{3}$, main adsorbed species was carbonate. We studied the adsorption of $\mathrm{CO}_{2}$ on $\mathrm{Ag}-\mathrm{Pd} / \mathrm{Al}_{2} \mathrm{O}_{3}$ at $200{ }^{\circ} \mathrm{C}$, but no peak at $1630 \mathrm{~cm}^{-1}$ was observed. The peak at $1637 \mathrm{~cm}^{-1}$ in Fig. 3 may be associated with the frequency of double bond stretching vibration, such as $v(\mathrm{C}=\mathrm{C}), v(\mathrm{C}=\mathrm{O})$. In general, the stretching vibration frequencies of isolate $\mathrm{C}=\mathrm{C}$ and $\mathrm{C}=\mathrm{O}$ should both be higher than $1637 \mathrm{~cm}^{-1}$. When exposing $\mathrm{Ag} / \mathrm{Al}_{2} \mathrm{O}_{3}$ to the flow of $\mathrm{C}_{3} \mathrm{H}_{6}+\mathrm{O}_{2}$, it is possible to form a surface enolic structure $\left(\mathrm{H}_{2} \mathrm{C}=\mathrm{CH}-\mathrm{O} \cdots \mathrm{M}^{+}\right)$ on the surface by partial oxidation of $\mathrm{C}_{3} \mathrm{H}_{6}$. The conjugation of $\mathrm{H}_{2} \mathrm{C}=\mathrm{CH}-\mathrm{O}^{-}$group may induce the vibrational mode of $\mathrm{C}-\mathrm{C}-\mathrm{O}$ to shift to a frequency which is lower than $v(\mathrm{C}=\mathrm{C})$ and higher than $v(\mathrm{C}-\mathrm{O})$ [26]. As a consequence, the peak at $1637 \mathrm{~cm}^{-1}$ in Fig. 3 could be tentatively assigned to stretching vibration mode of $\mathrm{C}=\mathrm{CH}-\mathrm{O}^{-}$. With increasing temperature, the bands of nitrate $\left(1300 \mathrm{~cm}^{-1}\right)$ and enolic species $\left(1637 \mathrm{~cm}^{-1}\right)$ decreased promptly, while the -NCO band $\left(2233 \mathrm{~cm}^{-1}\right)$ progressively appeared. This indicates that the enolic surface species is reactive towards nitrate to form $-\mathrm{NCO}$ species. As a result, $\mathrm{Ag}-\mathrm{Pd} / \mathrm{Al}_{2} \mathrm{O}_{3}$ has a higher $-\mathrm{NCO}$ surface concentration than $\mathrm{Ag} / \mathrm{Al}_{2} \mathrm{O}_{3}$ during the SCR of NO by $\mathrm{C}_{3} \mathrm{H}_{6}$. This result is in good agreement with activity of $\mathrm{Ag} / \mathrm{Al}_{2} \mathrm{O}_{3}$ and $\mathrm{Ag}-\mathrm{Pd} / \mathrm{Al}_{2} \mathrm{O}_{3}$.

\subsection{Reaction mechanism on $\mathrm{Ag}-\mathrm{Pd} / \mathrm{Al}_{2} \mathrm{O}_{3}$}

The reaction mechanism of the SCR of NO by $\mathrm{C}_{3} \mathrm{H}_{6}$ over $\mathrm{Ag} / \mathrm{Al}_{2} \mathrm{O}_{3}$ has been proposed with $\mathrm{R}-\mathrm{ONO}, \mathrm{R}-\mathrm{NO}_{2}$ and $-\mathrm{NCO}$ as the key intermediates 


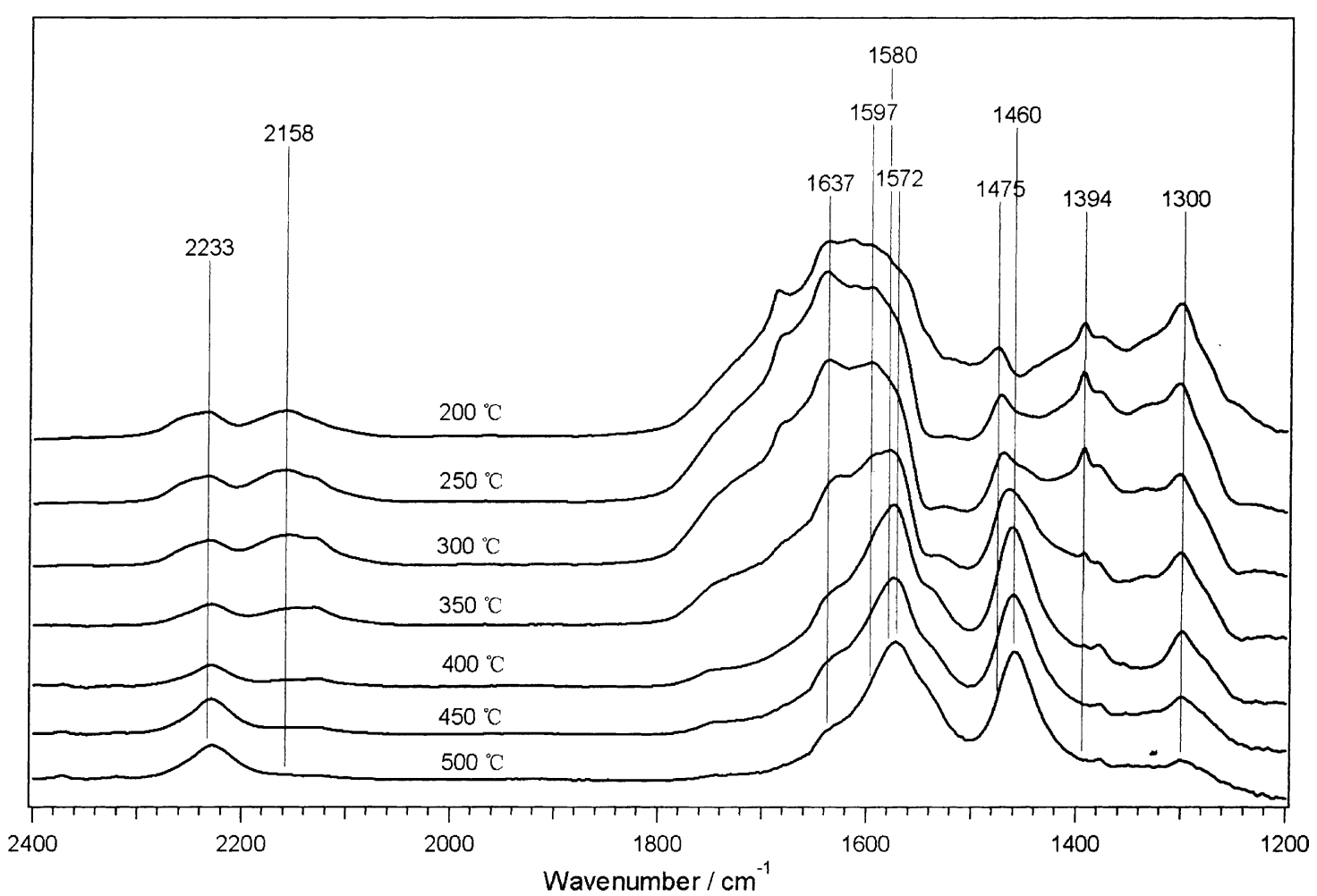

Fig. 3. In situ DRIFTS spectra of $\mathrm{Ag}-\mathrm{Pd} / \mathrm{Al}_{2} \mathrm{O}_{3}$ in a steady state at various temperatures in a flow of $\mathrm{C}_{3} \mathrm{H}_{6}+\mathrm{O}_{2}+\mathrm{NO}$. Feed: the same as in Fig. 1.

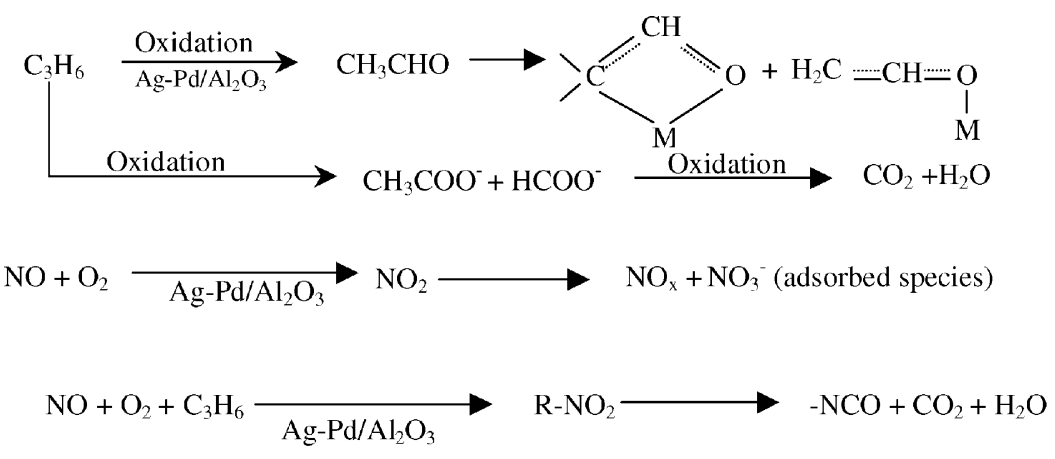<smiles>[M]O[CH+]C1(C)C=[Y](OC)O1</smiles>

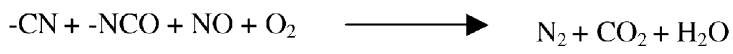

Scheme 1. The proposed reaction mechanism for the SCR of $\mathrm{NO}$ by $\mathrm{C}_{3} \mathrm{H}_{6}$ over $\mathrm{Ag}-\mathrm{Pd} / \mathrm{Al}_{2} \mathrm{O}_{3}$. 
$[10,12,20]$. Burch et al. [14] extended a similar reaction mechanism to all oxide catalysts in a review, approximately, $\mathrm{NO}+\mathrm{O}_{2}+\mathrm{C}_{3} \mathrm{H}_{6} \rightarrow \mathrm{NO}_{x}+\mathrm{C}_{x} \mathrm{H}_{y} \mathrm{O}_{z} \rightarrow$ $\mathrm{R}-\mathrm{NO}_{2}+\mathrm{R}-\mathrm{ONO} \rightarrow \mathrm{R}-\mathrm{NCO}+\mathrm{R}-\mathrm{CN}+\mathrm{NO}+\mathrm{O}_{2} \rightarrow$ $\mathrm{N}_{2}$. Our in situ DRIFTS in Fig. 2 also support this mechanism. $\mathrm{R}-\mathrm{ONO}, \mathrm{R}-\mathrm{NO}_{2}$ and $-\mathrm{NCO}$ are observed on $\mathrm{Ag} / \mathrm{Al}_{2} \mathrm{O}_{3}$ during reaction, and high coverage R-ONO formed at a low temperature of $200^{\circ} \mathrm{C}$. However, the mechanism is dramatically altered with adding a trace quantity of $\mathrm{Pd}$ to $\mathrm{Ag} / \mathrm{Al}_{2} \mathrm{O}_{3}$. In the case of $\mathrm{Ag}-\mathrm{Pd} / \mathrm{Al}_{2} \mathrm{O}_{3}$, R-ONO band at $1651 \mathrm{~cm}^{-1}$ cannot be observed at all reaction temperatures, replaced with the enolic species band at $1637 \mathrm{~cm}^{-1}$ (Fig. 3). It can be considered that the presence of Pd catalyzes the formation of enolic species, which undergoes a reaction with $\mathrm{NO}_{2}$ and $\mathrm{NO}_{3}{ }^{-}$to convert into $-\mathrm{NCO}$ and $-\mathrm{CN}$, and subsequently into $\mathrm{N}_{2}$. Summarizing the mentioned discussion, the proposed reaction pathway of the SCR of $\mathrm{NO}$ by $\mathrm{C}_{3} \mathrm{H}_{6}$ over $\mathrm{Ag}-\mathrm{Pd} / \mathrm{Al}_{2} \mathrm{O}_{3}$ is illustrated in Scheme 1.

Much additional knowledge will be required before reliable reaction mechanism can be made. Further studies are under way in order to test some of the hypotheses made above.

\section{Conclusion}

We have developed a novel $\mathrm{Ag}-\mathrm{Pd} / \mathrm{Al}_{2} \mathrm{O}_{3}$ catalyst for the $\mathrm{NO}_{x}$ reduction by $\mathrm{C}_{3} \mathrm{H}_{6}$ under lean burning conditions. According to catalytic tests over $\mathrm{Ag}-\mathrm{Pd} / \mathrm{Al}_{2} \mathrm{O}_{3}$ and contrastive $\mathrm{Ag} / \mathrm{Al}_{2} \mathrm{O}_{3}$, we find that loading trace amounts of $\mathrm{Pd}$ on $\mathrm{Ag} / \mathrm{Al}_{2} \mathrm{O}_{3}$ leads to a significant improvement of $\mathrm{NO}_{x}$ conversion during the SCR of $\mathrm{NO}$ by $\mathrm{C}_{3} \mathrm{H}_{6}$, especially at low reaction temperature. In situ DRIFTS results suggest that $\mathrm{Pd}$ addition catalyzes the partial oxidation of $\mathrm{C}_{3} \mathrm{H}_{6}$ into surface enolic species, and the surface enolic species is quite reactive towards $\mathrm{NO}_{3}{ }^{-}$and $\mathrm{NO}_{2}$ to form surface NCO species. Based on these results, a new reaction mechanism is proposed with enolic species and NCO species as the key reaction intermediates.

\section{Acknowledgements}

This work was financially supported by State Hi-tech Research and Development Project of the
Ministry of Science and Technology, PR China (Grant 2001AA643040) and the Chinese Academy of Sciences Program for Attracting Overseas Professionals.

\section{References}

[1] M. Iwamoto, in: Proceedings of the Symposium on Catalytic Technology for the Removal of Nitrogen Oxides, Catalytic Society of Japan, 1990, p. 19.

[2] M. Iwamoto, H. Yahiro, S. Shundo, Y. Yu, N. Mizuno, Appl. Catal. 69 (1991) L15.

[3] W. Held, A. Köenig, T. Richiter, L. Puppe, SAE Paper 900496, 1990.

[4] T. Miyadera, K. Yoshida, Chem. Lett. 3 (1993) 1483; T. Miyadera, Appl. Catal. B 2 (1993) 199.

[5] K.A. Bethke, H.H. Kung, J. Catal. 172 (1997) 93.

[6] K. Shimizu, H. Maeshuma, A. Satsuma, T. Hattori, Appl. Catal. B 18 (1998) 163.

[7] F.C. Meunier, J.P. Breen, V. Zuzaniuk, M. Olsson, J.R.H. Ross, J. Catal. 187 (1999) 493.

[8] K. Shimizu, A. Satsuma, T. Hattori, Appl. Catal. B 25 (2000) 239.

[9] S. Kameoka, Y. Ukisu, T. Miyadera, Phys. Chem. Chem. Phys. 2 (2000) 367.

[10] F.C. Meunier, V. Zuzaniuk, J.P. Breen, M. Olsson, J.R.H. Ross, Catal. Today 59 (2000) 287.

[11] S. Sumiya, M. Saito, H. He, Q.-C. Feng, N. Takezawa, Catal. Lett. 50 (1998) 87.

[12] S. Sumiya, H. He, A. Abe, N. Takezawa, K.J. Yoshida, J. Chem. Soc., Faraday Trans. 94 (1998) 2217.

[13] A. Obuchi, A. Ohi, M. Nakamura, A. Ogata, K. Mizuno, H. Ohuchi, Appl. Catal. B 2 (1993) 71.

[14] R. Burch, J.P. Breen, F.C. Meunier, Appl. Catal. B 39 (2002) 283.

[15] H. He, N. Irite, K. Onai, K. Yoshida, in: Proceedings of the 69th Annual Meeting of Chemical Society of Japan, 1995, p. A314.

[16] K. Masuda, K. Shinoda, T. Kato, K. Tsujimura, Appl. Catal. B 15 (1998) 29.

[17] E. Seker, J. Cavataio, E. Gulari, P. Lorpongpaiboon, S. Osuwan, Appl. Catal. A 183 (1999) 121.

[18] M. Haneda, Y. Kintaichi, M. Inaba, H. Hamada, Appl. Surf. Sci. 121-122 (1997) 391.

[19] T. Tanaka, T. Okuhara, M. Misono, Appl. Catal. B 4 (1994) L1.

[20] K. Shimizu, J. Shibata, H. Yoshida, A. Satsuma, T. Hattori, Appl. Catal. B 30 (2001) 151.

[21] K. Shimizu, H. Kawabata, A. Satuma, T. Hattori, Appl. Catal. B 19 (1998) L87.

[22] K. Shimizu, A. Satsuma, T. Hattori, Appl. Catal. B 25 (2000) 239.

[23] A. Martínez-Arisa, M. Fenández-García, A. Glesias-Juez, J.A. Anderson, J.C. Conesa, J. Soria, Appl. Catal. B 28 (2000) 29.

[24] K. Shimizu, H. Kawabata, H. Maeshima, A. Satuma, T. Hattori, J. Phys. Chem. B 104 (2000) 2885.

[25] A.M. Turek, I.E. Wachs, E. DeCanio, J. Phys. Chem. 96 (1992) 5000.

[26] Standard IR Spectra, Sadtler Research Labs. 